Int. J. Dev. Biol. 59: 179-186 (2015)

doi: $10.1387 / \mathrm{ijdb} .150042 \mathrm{fh}$

\title{
SCNT versus iPSCs: proteins and small molecules in reprogramming
}

\author{
FEI HAN\#, XIA LI\#, DANDAN SONG, SHAOSHUAI JIANG, QUN XU and YUNHAI ZHANG* \\ Anhui Provincial Laboratory for Local Livestock and Poultry Genetic Resource Conservation and Breeding, College \\ of Animal Science and Technology, Anhui Agricultural University, Hefei, China
}

\begin{abstract}
Somatic cell nuclear transplantation (SCNT) and induced pluripotent stem cell (iPSC) technologies can be employed to change cell fate by reprogramming. The discoveries of SCNT and iPSCs were awarded the Nobel Prize for Physiology and Medicine in 2012, which reaffirmed the importance of cell fate plasticity. However, the low cloning efficiency of SCNT and differences between iPSCs and embryonic stem cells (ESCs) are great barriers and may be caused by incomplete or aberrant reprogramming. Additionally, the well characterized reprogramming factors Oct4, Sox2, KIf4 and c-Myc (OSKM) are not simultaneously expressed at high levels in enucleated or early embryonic oocytes, suggesting reprogramming may be different in the above two methods. Recent studies have demonstrated that small molecules and specific proteins expressed in oocytes and in early embryonic development play important roles in reprogramming by replacing transcription factors, erasing reprogramming memory and accelerating the speed and extent of reprogramming. In this review, we summarize the current state of SCNT and iPSCs technologies and discuss the latest advances in the research of proteins and small molecules affecting SCNT and iPSCs. This is an area of research in which chemical biology and proteomics are combining to facilitate improving cellular reprogramming and production of clinical grade iPSCs.
\end{abstract}

KEY WORDS: SCNT, iPSC, early embryo, oocyte, differentiation, protein, small molecule

\section{Introduction}

Each and every one of us developed from a totipotent egg following fertilization, and the journey of embryonic development from immature to specialized cells was previously considered to be unidirectional. However, in 1962, Gurdon (Gurdon, 1962) provided the first evidence that broke from this dogmatic view and demonstrated that specialization of cells is reversible by somatic cell nuclear transplantation (SCNT) in frogs. Since then, SCNT has been used to clone sheep (Wilmut et al., 1997) and pigs (Betthauser et al., 2000), and following great efforts, SCNT-derived human embryonic stem cells (ESCs) were finally generated from fetal dermal fibroblasts in 2013 (Tachibana et al., 2013) and from 35- and 75-year-old males in 2014 (Chung et al., 2014). Subsequently, adult somatic nuclei from newborn and adult female patients with type 1 diabetes were reprogrammed in to diploid pluripotent stem cells. This work showed the potential for therapeutic applications (Yamada et al., 2014) and confirmed the suitability of SCNT for large mammals, and the research area is continuing to expand (Cibelli, 2014). However, the efficiency of acquiring healthy offspring and patient-specific stem cells using SCNT remains low, possibly due to incomplete or inappropriate reprogramming of the transferred nuclear genome (Campbell et al., 2007). Oocytes and early embryos perform crucial functions in SCNT-mediated reprogramming, and extracts of oocytes (Bui et al., 2012) have been used successfully to mediate somatic cell reprogramming. However, many of the cellular and macromolecular factors responsible for conferring totipotency or pluripotency to somatic cells remain unknown.

A current popular hypothesis assumes that the specific fac-

\footnotetext{
Abbreviations used in this paper: bFGF, FGF2, basic fibroblast growth factor; BMP, bone morphogenetic protein; ESCs, embryonic stem cells; GDF9, growth and differentiation factor 9; iPSCs, induced pluripotent stem cells; Lif, leukemia inhibitory factor; OSKM, reprogramming factors Oct4, Sox2, Klf4 and c-Myc; PGCs, primodial germ cells; SCF, stem cell factor; SCNT, Somatic cell nuclear transplantation; SNEL, reprogramming factors Sall4, Nanog, Esrrb, and Lin28; TLR3, toll-like receptor 3.
}

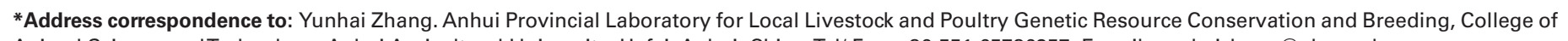
Animal Science and Technology, Anhui Agricultural University, Hefei, Anhui, China. Tel/ Fax: +86-551-65786357; E-mail: yunhaizhang@ahau.edu.cn

"These authors contributed equally to this work.

Accepted: 14 May 2015.

ISSN: Online 1696-3547, Print 0214-6282

(C) 2015 UBC Press

Printed in Spain 
TABLE 1

\section{KEY INFORMATION ON SCNT IN DIFFERENT SPECIES}

\begin{tabular}{|c|c|c|c|}
\hline Date, Species and Author & Donor cell & Injection method & Cloning efficiency \\
\hline $\begin{array}{l}1997 \text { Sheep } \\
\text { Wilmut et al. }\end{array}$ & $\begin{array}{l}\text { mammary gland cell } \\
\text { G0 phase }\end{array}$ & $\begin{array}{l}\text { Perivitelline injection } \\
\text { none }\end{array}$ & none \\
\hline $\begin{array}{l}1998 \text { Calf } \\
\text { Cibelli et al. }\end{array}$ & $\begin{array}{l}\text { fetal fibroblasts } \\
\text { G1 phase }\end{array}$ & $\begin{array}{l}\text { none } \\
\text { MIl stage }\end{array}$ & $2.2 \%$ \\
\hline $\begin{array}{l}1998 \text { Mouse } \\
\text { Wakayama T et al. }\end{array}$ & $\begin{array}{l}\text { cumulus cell } \\
\text { G0/G1 phase }\end{array}$ & $\begin{array}{l}\text { Cytoplasmic injection } \\
\text { MII stage }\end{array}$ & $5.1 \%$ \\
\hline $\begin{array}{l}1999 \text { Goat } \\
\text { Baguisi A et al. }\end{array}$ & $\begin{array}{l}\text { fetal fibroblasts } \\
\text { G1phase }\end{array}$ & $\begin{array}{l}\text { Perivitelline injection } \\
\text { MII / TII stage }\end{array}$ & $6.5 \%$ \\
\hline $\begin{array}{l}2000 \text { Pig } \\
\text { Polejaeva I A et al. }\end{array}$ & $\begin{array}{l}\text { granulosa cell } \\
\text { G0/G1 phase }\end{array}$ & $\begin{array}{l}\text { Perivitelline } \\
\text { Mll stage }\end{array}$ & none \\
\hline $\begin{array}{l}2002 \text { Cat } \\
\text { Shin et al. }\end{array}$ & $\begin{array}{l}\text { adult fibroblasts } \\
\text { cumulus cell } \\
\text { none }\end{array}$ & $\begin{array}{l}\text { Perivitelline injection } \\
\text { MIl stage }\end{array}$ & $0.5 \%$ \\
\hline $\begin{array}{l}2002 \text { Rabbit } \\
\text { Chesné et al. }\end{array}$ & $\begin{array}{l}\text { cumulus cell } \\
\text { none }\end{array}$ & $\begin{array}{l}\text { Perivitelline injection } \\
\text { MIl stage }\end{array}$ & $1.3 \%$ \\
\hline $\begin{array}{l}2003 \text { Horse } \\
\text { Galli et al. }\end{array}$ & $\begin{array}{l}\text { adult fibroblasts } \\
\text { none }\end{array}$ & $\begin{array}{l}\text { Cell fusion } \\
\text { Mll stage }\end{array}$ & $0.8 \%$ \\
\hline $\begin{array}{l}2005 \text { Dog } \\
\text { Lee B C et al. }\end{array}$ & $\begin{array}{l}\text { ear skin fibroblasts } \\
\text { none }\end{array}$ & $\begin{array}{l}\text { Perivitelline injection } \\
\text { MIl stage }\end{array}$ & none \\
\hline $\begin{array}{l}2006 \text { Ferrets } \\
\text { Ziyi Li et al. }\end{array}$ & $\begin{array}{l}\text { fetal fibroblasts } \\
\text { none }\end{array}$ & $\begin{array}{l}\text { Cell fusion } \\
\text { Mll stage }\end{array}$ & none \\
\hline $\begin{array}{l}2007 \text { Buffalos } \\
\text { Shi D et al. }\end{array}$ & $\begin{array}{l}\text { fetal fibroblasts } \\
\text { and granulosa cell } \\
\text { G0/G1 phase }\end{array}$ & $\begin{array}{l}\text { Perivitelline injection } \\
\text { MII stage }\end{array}$ & none \\
\hline
\end{tabular}

Note: none represents no related information in the research. Cloning efficiency represents fetal / nuclear transfer embryos. G0/G1 represents Gap 0/Gap 1. MII represents metaphase II.

tors playing important roles in the maintenance of ESCs' identity also play pivotal roles in the induction of pluripotency in somatic cells. Takahashi et al., acquired iPSCs from mouse and human somatic cells using retroviruses, and these cells have the ability to replicate indefinitely while maintaining pluripotency and the ability to differentiate into cells of all three germ layers (Takahashi and Yamanaka, 2006, Yu et al., 2007). These cells circumvent the need for human embryos and can reduce or avoid immune rejection by generating stem cells from the patient's own cells. Therefore, iPSCs provide an attractive alternative to ESCs and hold great promise for disease modeling, drug selection and cell therapies in both regenerative medicine and agriculture ( $\mathrm{Li}$ et al., 2014). A year after human iPSCs were generated for the first time, various disease-specific iPSCs were produced that offer an unprecedented opportunity to recapitulate both normal and diseased human tissues in vitro (Park et al., 2008). Owing to the capacity of proliferating indefinitely, iPSCs show a high efficiency for gene targeting (Hockemeyer et al., 2009), which may have implications for treating diseases resulting from genetic defects. In 2013, using human iPSCs-derived cardiomyocytes from patients with hereditary cardiac disorders, Liang et al., (Liang et al., 2013) demonstrated the power of patient-specific iPSCs in drug selection and drug toxicity screening for establishing the optimum drug dosage for specific patients. However, low efficiency, genome instability and epigenetic memories of donor cells during reprogramming remain barriers to the future clinical use of iPSCs.

At present, achieving a perfect reprogramming method appears to be some way off. A recent comparison of SCNT and iPSCs technologies found that both can cause subtle molecular defects (Krupalnik and Hanna, 2014). In this review, we further explore the similarities, differences and the advantages, disadvantages of these methods. Compared to SCNT, iPSCs and early embryos may provide insight into possible perfect reprogramming approaches, and may be useful for identifying proteins and small molecules in oocytes or early embryos that may be critical for this process. To this end, we have reviewed the source and function of such proteins and small molecules reported to date, and summarized the recent advances in SCNT and iPSCs technologies. The most promising approaches for producing high quality, safe and effective pluripotent stem cells using proteins and small molecules are given particular attention.

\section{The current state of SCNT and associated problems}

SCNT is a method of creating reconstructed embryos from somatic cells and oocytes that consists of implanting a donor nucleus from a somatic cell into an enucleated oocyte. This approach has produced viable offspring of a number of species for reproductive purposes, and has also generated patient-specific stem cell lines for therapeutic purposes (Fig. 1). Since the birth of Dolly the sheep, SCNT has been used to clone cattle (Cibelli et al., 1998), mice (Wakayama et al., 1998), goats (Baguisi et al., 1999), pigs (Polejaeva et al., 2000), cats (Shin et al., 2002), rabbits (Chesne et al., 2002), horses (Galli et al., 2003), rats (Zhou et al., 2003), dogs (Lee et al., 2005), and ferrets (Li et al., 2006) from a range of cell types (Table 1). Human ESCs (hESCs) have also been generated using SCNT and shown to be equivalent to ESCs from embryos in vivo studies (Chung et al., 2014, Tachibana et al., 2013, Yamada et al., 2014).

Despite multiple attempts, the efficiency of producing viable offspring by SCNT remains stubbornly low (Maruotti et al., 2010). This may be due to incomplete or aberrant reprogramming, and the

TABLE 2

\section{SUMMARY OF EXTRACTS FROM OOCYTES AND PLURIPOTENT CELLS MEDIATING REPROGRAMMING}

\begin{tabular}{|c|c|c|c|}
\hline Date and Authors & Extracts source and start cells types & Method of Permeable membrane & Mechanism \\
\hline $\begin{array}{l}2003 \\
\text { Byrne et al }\end{array}$ & $\begin{array}{l}\text { Xenopus laevis GV oocytes } \\
\text { Adult mouse thymocytes and adult human blood lymphocytes }\end{array}$ & $10-20$ streprtolysin for 7 days at $18^{\circ} \mathrm{C}$ & $\begin{array}{l}\text { Induce terminally differentiated mammalian cells to express } \\
\text { Oct4 }\end{array}$ \\
\hline $\begin{array}{l}2008 \\
\text { Bui et al. }\end{array}$ & $\begin{array}{l}\text { Mouse GV oocytes } \\
\text { Mouse cumulus cells }\end{array}$ & $200 \mathrm{ng} / \mathrm{ml}$ streptolysin $\mathrm{O}$ for $40 \mathrm{~min}$ at $37^{\circ} \mathrm{C}$ & $\begin{array}{l}\text { Genomic reprogramming factors are present in the } \\
\text { cytoplasm }\end{array}$ \\
\hline $\begin{array}{l}2010 \\
\text { Cho et al. }\end{array}$ & $\begin{array}{l}\text { Mouse embryonic stem cell-derived proteins } \\
\text { Mouse fibroblasts }\end{array}$ & $230 \mathrm{ng} / \mu \mathrm{l}$ streptolysin $\mathrm{O}$ for $50 \mathrm{~min}$ at $37^{\circ} \mathrm{C}$ & $\begin{array}{l}\text { Neither by the contamination of donor ESCs nor by } \\
\text { DNAs/RNAs from donor ESCs }\end{array}$ \\
\hline $\begin{array}{l}2011 \\
\text { Miyamoto et al. }\end{array}$ & $\begin{array}{l}\text { DJ-1 in oocyte proteins } \\
\text { Porcine fibroblasts cells }\end{array}$ & $30 \mu \mathrm{g} / \mathrm{ml}$ digitonin & Disturb expression of P53 pathway components \\
\hline $\begin{array}{l}2012 \\
\text { Bui et al. }\end{array}$ & $\begin{array}{l}\text { Pig GV oocytes } \\
\text { Porcine ear skin fibroblasts }\end{array}$ & $300 \mathrm{ng} / \mathrm{ml}$ streptolysin $\mathrm{O}$ for $50 \mathrm{~min}$ at $38.5^{\circ} \mathrm{C}$ & $\begin{array}{l}\text { Induce demethylation of H3-K9 } \\
\text { Promote Oct4-EGFP expression in SCNT-derived embryos }\end{array}$ \\
\hline $\begin{array}{l}2014 \\
\text { Kong et al. }\end{array}$ & $\begin{array}{l}\text { Pig oocytes with } 1^{\text {st }} \text { polarbody and maternal vimentin protein } \\
\text { Porcine ear fetal fibroblasts }\end{array}$ & none & $\begin{array}{l}\text { Inhibit DNA double-strand breaks } \\
\text { Down regulate p53 expression }\end{array}$ \\
\hline
\end{tabular}


exact molecular components influencing reprogramming in SCNT are poorly understood. Efficient reprogramming of differentiated cell nucleus can also be induced by oocyte extracts. Here, extracts from oocytes or pluripotent stem cells for successful efficient reprogramming have been shown in Table 2. These researches demonstrated that proteins and small compounds in oocyte and early embryos, not genetic materials, play vital roles in reprogramming process. But these proteins and small compounds in oocytes and early embryos still need to be defined and their potential functions and mechanisms are unclear.

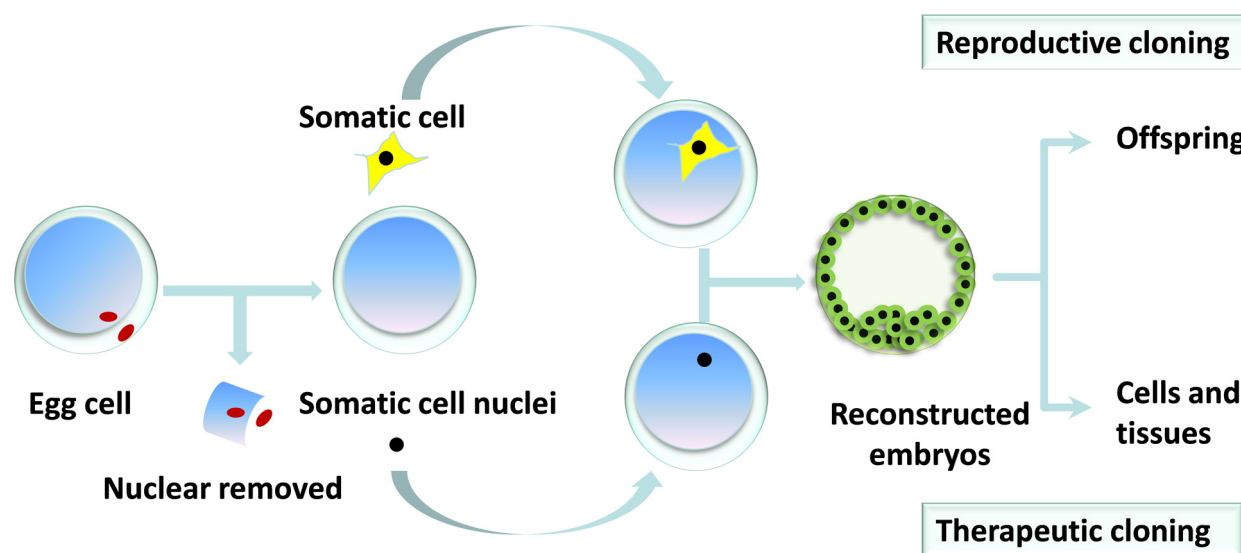

Fig. 1. Flow diagram and main purposes of somatic cell nuclear transplantation (SCNT).

\section{The current state of iPSCs and associated problems}

Through the ectopic expression of defined factors in mouse embryonic or adult fibroblasts, these differentiated cells can be reprogrammed to iPSCs (Takahashi and Yamanaka, 2006). Since iPSCs were first described, the use of these cells in the development of reprogramming technologies has been rapid, and numerous types of source cells have been employed. Researchers also use different methods to obtain iPSCs, including viral- and transgene-free methods, non-viral methods, and viral methods (Table 3). Though the last two methods are considered to take risk of genome integration, the first method is still immature, and further studies are needed for optimizing reprogramming process.

In general, these approaches up-regulate genes involved in pluripotency and self-renewal, and down-regulate lineage commitment genes (Krueger et al., 2010). Current prevailing reprogramming methods affect the quality of iPSCs and great strides have been made to improve the safety, efficiency and speed of these methods. In summary, eliminating oncogenes and adding new factors such as Sall4, Tbx3 and $\mathrm{Nr} 5 \alpha 2$ into reprogramming cocktails, adjusting existing factor combinations, and altering the proteins and small compounds present to reduce tumorigenicity have all been shown to affect the quality of the iPSCs produced (Han et al., 2010, Tsubooka et al., 2009, Wang et al., 2013). The stoichiometry of factors and the order in which they are introduced can also affect the speed and efficiency of reprogramming (Liu et al., 2013). For instance, iPSCs based on tetraploid complementation that were generated in mouse embryonic fibroblasts (MEFs) by ectopic Sall4, Nanog, Esrrb, and Lin28 (SNEL) were of higher quality than classic Oct4, Sox2, Klf4 and c-Myc (OSKM)-derived cells (Buganim et al., 2014).

At present, iPSCs technologies face the problems of reprogramming extent, memory, and immunogenicity. The pluripotent genes Fbx15, Oct4 and Nanog combined with drug-resistance genes and cloning morphologies have been used to screen positive cell lines (Takahashi and Yamanaka, 2006). At the early stages of reprogramming, iPSCs are always partially reprogrammed and possess limited differentiation potential. For example, the first iPSCs line could not produce adult chimeras and exhibited no germ transmission capacity (Okita et al., 2007, Takahashi and Yamanaka, 2006). However, these partially reprogrammed cells proved powerful for investigation of reprogramming mechanisms. Meanwhile, partially reprogrammed iPSCs can elicit immune rejection (Martins-Taylor and $\mathrm{Xu}, 2012$, Polo et al., 2010). Although controversy concerning the immunogenicity of iPSCs remains all the time, the immunogenicity of iPSCs generated by a viral integration approach was higher than that of cells derived by an episomal method without genomic integration (Zhao et al., 2011). These results suggest that iPSCs derived by viral-free and gene-free methods, such as protein- or small molecule-mediated methods, may result in lower

TABLE 3

\section{CHARACTERISTICS, PROS AND CONS OF IPSC GENERATION METHODS}

\begin{tabular}{|c|c|c|c|}
\hline $\begin{array}{l}\text { Date and } \\
\text { authors }\end{array}$ & Delivery method & Pros & Cons \\
\hline \multicolumn{4}{|l|}{ Viral methods } \\
\hline $\begin{array}{l}2007 \\
\text { Okita et al. }\end{array}$ & Retroviral & Fairly efficient & $\begin{array}{l}\text { Genome integration, } \\
\text { possible reactivation of viral } \\
\text { genes }\end{array}$ \\
\hline $\begin{array}{l}2014 \\
\text { Zhang et al. }\end{array}$ & Lentiviral & Very efficient & $\begin{array}{l}\text { Genome integration, } \\
\text { possible reactivation of viral } \\
\text { genes }\end{array}$ \\
\hline $\begin{array}{l}2008 \\
\text { Stadtfeld et al. }\end{array}$ & Adenoviral & No genome integration & Low efficiency, \\
\hline $\begin{array}{l}2008 \\
\text { Stadtfeld et al. }\end{array}$ & Sendai virus & No genome integration & $\begin{array}{l}\text { Low efficiency, } \\
\text { possible reactivation of viral } \\
\text { genes }\end{array}$ \\
\hline \multicolumn{4}{|c|}{ Non-viral methods } \\
\hline $\begin{array}{l}2011 \\
\text { Okita et al. }\end{array}$ & Plasmid/DNA & $\begin{array}{l}\text { Low genomic integration } \\
\text { Non-viral, possible to carry } \\
\text { large DNA fragments }\end{array}$ & $\begin{array}{l}\text { Risk of genome integration, } \\
\text { Low efficiency } \\
\text { Repeated transfections }\end{array}$ \\
\hline $\begin{array}{l}2009 \\
\text { Yu et al. }\end{array}$ & Episomal & $\begin{array}{l}\text { Low genomic integration } \\
\text { Non-viral, possible to carry } \\
\text { large DNA fragments, no } \\
\text { need for repeated } \\
\text { transfections }\end{array}$ & $\begin{array}{l}\text { Risk of genome integration, } \\
\text { Low efficiency }\end{array}$ \\
\hline \multicolumn{4}{|c|}{ Viral- and transgene-free methods } \\
\hline $\begin{array}{l}2010 \\
\text { Warren et al. }\end{array}$ & mRNA & $\begin{array}{l}\text { Non-viral, high efficiency, } \\
\text { No genome integration, } \\
\text { controllable cellular } \\
\text { delivery }\end{array}$ & $\begin{array}{l}\text { Need repeated transfections, } \\
\text { exist immunogenic effect, } \\
\text { expensive }\end{array}$ \\
\hline $\begin{array}{l}2011 \\
\text { Miyoahi et al. }\end{array}$ & MicroRNA & $\begin{array}{l}\text { Non-viral, fairly efficiency, } \\
\text { no genome integration, } \\
\text { fast }\end{array}$ & Poor repeated \\
\hline $\begin{array}{l}2009 \\
\text { Kim et al. }\end{array}$ & Protein & $\begin{array}{l}\text { No genome integration, } \\
\text { non-viral }\end{array}$ & $\begin{array}{l}\text { Low efficiency, need large } \\
\text { amounts of pure and } \\
\text { bioactivity proteins }\end{array}$ \\
\hline $\begin{array}{l}2013 \\
\text { Hou et al. }\end{array}$ & Small compounds & $\begin{array}{l}\text { Non-viral, high efficiency, } \\
\text { no genome integration }\end{array}$ & Poor repeated \\
\hline
\end{tabular}


immunogenicity. On the other hand, the origin of the cell type can also influence the immune properties of iPSCs, possibly due to differences in reprogramming memory (Polo et al., 2010). The difference in transcription and epigenetic landscape between ESCs and iPSCs is that the latter type bearing some memory of their original differentiated state (Eguchi et al., 2014). The memory of iPSCs can result in the partial retention of the transcriptional and epigenetic features of the source cells. Additionally, iPSCs tend to differentiate into source cells when differentiation is induced. Interestingly, this phenomenon gradually disappears with multiple passages (Lee et al., 2014). In 2013, Kumar et al., (Kumar et al., 2013) found that inducing the enzyme cytidine deaminase could diminish the epigenetic memory of iPSCs, resulting in a stable pluripotent state.

\section{Proteins and small molecules in SCNT and iPSCs}

In 1981, mouse ESCs (mESCs) were obtained from blastocyst pluripotent epiblast cells and cultured with inactivated fibroblast feeders, serum and other ingredients (Evans and Kaufman, 1981). It was found that cytokines from the feeder cells or serum such as leukegmia inhibitory factor (Lif) (Gardner and Brook, 1997) and bone morphogenetic protein (BMP) (Ying et al., 2003) were essential for maintenance of pluripotency. Approximately 20 years later, hESCs were first reported (Thomson et al., 1998). In apparent contrast to mESCs, Lif (Humphrey et al., 2004, Thomson et al., 1998) and BMP (Xu et al., 2002) have been shown to induce differentiation in hESCs. In contrast, basic fibroblast growth factor (bFGF) greatly promoted the self-renewal of hESCs (Amit et al., 2000). Therefore, researchers realized small molecules may cause distinct states of pluripotent in stem cells in mouse and human. In 2009, Nichols and Smith (Nichols and Smith, 2009) proposed that two phases of pluripotency can be defined: naïve and primed. The mESCs are naïve pluripotent state and lead to broad and more robust developmental potential relative to primed mouse epiblast cells and hESCs. Then, Hanna et al., (Hanna et al., 2010) acquired naïve human ESCs/iPSCs which could grow on feeder cells in PD0325901/CHIR99021/Lif/Forskolin. After that, Ware et al., (Ware et al., 2014) also described two routes to generate naïve $\mathrm{hESCs}$ by some small molecules and proteins like MEK/ERK and GSK3 inhibitors with FGF2. These studies suggest that specific proteins and small molecules play an important role in establishing and maintaining the pluripotency of ESCs among different species, and even the pluripotent state can inter-convert through different combinations of small compouds and proteins.

Small molecules can be highly influential in reprogramming procedures. During the early stages of reprogramming, activation of the toll-like receptor 3 (TLR3) innate immunity pathway was shown to be required for efficient nuclear reprogramming by comparing the viral and protein delivery of reprogramming factors (Lee et al., 2012). Furthermore, TLR3 activation was implemented by Poly I:C, a type of TLR3 agonist. More recently, Notch inhibition was shown to facilitate oncogene-independent generation of mouse and human iPSCs (Ichida et al., 2014).

One hypothesis that accounts for the enhanced reprogramming capacity posits that current strategies for inducing pluripotent stem cells lack oocyte-specific factors (Gonzalez-Munoz et al., 2014) such as BMPs, GDF9 (Paradis et al., 2009) and ASF1A (Kocabas et al., 2006) that are specifically enriched in oocytes, early embryos. Furthermore, these factors could also contribute to achieving more efficient reprogramming and illuminating the molecular pathways involved (Table 4). There are many more factors in oocytes and early embryos that may perform vital functions in reprogramming, many of which are untested for iPSCs generation (Table 5).

TABLE 4

\section{PROTEINS AND SMALL MOLECULES IN OOCYTES THAT IMPROVE IPSC QUALITY AND SAFETY}

\begin{tabular}{|c|c|c|c|c|}
\hline Chemicals kinds & Date and Authors & Species and cell types & Methods and factors & Functions \\
\hline \multirow{3}{*}{$\begin{array}{l}\text { LIF } \\
\text { bFGF } \\
\text { SCF }\end{array}$} & $\begin{array}{l}2006 \\
\text { Takahashi et al. }\end{array}$ & $\begin{array}{l}\text { Mouse } \\
\text { MEFs }\end{array}$ & $\begin{array}{l}\text { Retrovirus } \\
\text { OSKM }\end{array}$ & \multirow[t]{3}{*}{ Give rise to iPSCs } \\
\hline & $\begin{array}{l}2007 \\
\text { Takahashi et al. }\end{array}$ & $\begin{array}{l}\text { Human } \\
\text { Fibroblasts }\end{array}$ & $\begin{array}{l}\text { Retrovirus } \\
\text { OSKM }\end{array}$ & \\
\hline & $\begin{array}{l}2014 \\
\text { Kimura et al. }\end{array}$ & $\begin{array}{l}\text { Mouse } \\
\text { PGCs }\end{array}$ & $\begin{array}{l}\text { Retrovirus } \\
\text { OSKM }\end{array}$ & \\
\hline \multirow[t]{3}{*}{$\begin{array}{l}\text { PD0325901 } \\
\text { CHIR99021 }\end{array}$} & $\begin{array}{l}2008 \\
\text { Silva et al. }\end{array}$ & $\begin{array}{l}\text { Mouse } \\
\text { NSCs }\end{array}$ & $\begin{array}{l}\text { Retrovirus } \\
\text { OSKM }\end{array}$ & \multirow{3}{*}{$\begin{array}{l}\text { ERK and GSK3b inhibitors, } \\
\text { Improve reprogramming efficiency } \\
\text { Convert pre-iPSCs into iPSCs }\end{array}$} \\
\hline & $\begin{array}{l}2009 \\
\text { Esteban et al. }\end{array}$ & $\begin{array}{l}\text { Pig } \\
\text { PEFs }\end{array}$ & Lentiviruses OSKM & \\
\hline & $\begin{array}{l}2009 \\
\text { Lin et al. }\end{array}$ & $\begin{array}{l}\text { Human } \\
\text { Fibroblasts }\end{array}$ & $\begin{array}{l}\text { Retrovirus } \\
\text { OSKM }\end{array}$ & \\
\hline \multirow[t]{3}{*}{ Vitamin C } & $\begin{array}{l}2010 \\
\text { Esteban et al. }\end{array}$ & $\begin{array}{l}\text { Mouse/Human } \\
\text { Somatic Cells }\end{array}$ & $\begin{array}{l}\text { Retrovirus } \\
\text { OSKM }\end{array}$ & \multirow{3}{*}{$\begin{array}{l}\text { Convert pre-iPSCs into iPSCs, } \\
\text { Improve reprogramming speed and efficiency, } \\
\text { Modulate TET } 1 \text { function, } \\
\text { Promote the demethylation of } \mathrm{H} 3 \mathrm{~K} 36 \mathrm{me} 2 / \mathrm{me} 3\end{array}$} \\
\hline & $\begin{array}{l}2011 \\
\text { Wang et al. }\end{array}$ & $\begin{array}{l}\text { Mouse } \\
\text { MEFs }\end{array}$ & $\begin{array}{l}\text { Retrovirus } \\
\text { OSK }\end{array}$ & \\
\hline & $\begin{array}{l}2013 \\
\text { Chen et al. }\end{array}$ & $\begin{array}{l}\text { Mouse } \\
\text { Somatic Cells }\end{array}$ & $\begin{array}{l}\text { Retrovirus } \\
\text { OSK }\end{array}$ & \\
\hline \multirow[t]{2}{*}{$\begin{array}{l}\text { BMP } \\
\text { GDF9 }\end{array}$} & $\begin{array}{l}2010 \\
\text { Samavarchi-Tehrani et al. }\end{array}$ & $\begin{array}{l}\text { Mouse } \\
\text { MEFs }\end{array}$ & $\begin{array}{l}\text { piggyback transposition } \\
\text { OSKM }\end{array}$ & \multirow[t]{2}{*}{$\begin{array}{l}\text { BMP drive a MET transition, } \\
\text { Replace some factors }\end{array}$} \\
\hline & $\begin{array}{l}2011 \\
\text { Chen et al. }\end{array}$ & $\begin{array}{l}\text { Mouse } \\
\text { MEFs }\end{array}$ & $\begin{array}{l}\text { Retrovirus } \\
\text { Oct4 }\end{array}$ & \\
\hline \multirow[t]{2}{*}{ Deng's factors } & $\begin{array}{l}2011 \\
\text { Li et al. }\end{array}$ & Mouse Fibroblasts & $\begin{array}{l}\text { Lentiviruses } \\
\text { Oct4 }\end{array}$ & \multirow[t]{2}{*}{$\begin{array}{l}\text { Replace some factors, } \\
\text { Improve reprogramming efficiency }\end{array}$} \\
\hline & $\begin{array}{l}2013 \\
\text { Hou et al. }\end{array}$ & Mouse & Compounds & \\
\hline GATA protein family & $\begin{array}{l}2015 \\
\text { Shu et al. }\end{array}$ & $\begin{array}{l}\text { Mouse } \\
\text { Somatic cells }\end{array}$ & $\begin{array}{l}\text { Lentiviruses } \\
\text { SKM }\end{array}$ & inducers for cellular reprogramming to pluripotency \\
\hline
\end{tabular}


TABLE 5

PROTEINS AND SMALL MOLECULES IN OOCYTES AND EARLY EMBRYOS MEDIATING REPROGRAMMING

\begin{tabular}{|c|c|c|c|}
\hline Date and authors & Species & Factors and source & Functions and mechanism \\
\hline $\begin{array}{l}2011 \\
\text { Maekawa et al. }\end{array}$ & Mouse and Human & $\begin{array}{l}\text { Glis1 } \\
\text { Enriched in oocytes and one-cell-stage embryos }\end{array}$ & $\begin{array}{l}\text { a GLI transcription factor } \\
\text { Promote multiple pro-reprogramming pathways including Myc, Nanog, } \\
\text { and Lin28 }\end{array}$ \\
\hline $\begin{array}{l}2011 \\
\text { Kei Miyamoto } \\
\text { et al. }\end{array}$ & Porcine & $\begin{array}{l}\text { DJ-1 } \\
\text { Enriched in germinal vesicle stage oocytes to four-cell-stage } \\
\text { embryos }\end{array}$ & $\begin{array}{l}\text { Dimeric protein } \\
\text { Inhibition shows perturbed expression of P53 pathway components }\end{array}$ \\
\hline $\begin{array}{l}2013 \\
\text { Shinagawa et al. }\end{array}$ & Mouse & $\begin{array}{l}\text { TH2A and TH2B } \\
\text { Enriched in zygotes, decreases in differentiation into blastocysts }\end{array}$ & $\begin{array}{l}\text { Histone variants } \\
\text { Inducing transcriptionally active and open chromatin }\end{array}$ \\
\hline $\begin{array}{l}2013 \\
\text { Yuran Song et al. }\end{array}$ & Porcine & $\begin{array}{l}\text { CBHA } \\
\text { none }\end{array}$ & $\begin{array}{l}\text { Histone deacetylase inhibitor } \\
\text { Increases global histone acetylation levels }\end{array}$ \\
\hline $\begin{array}{l}2013 \\
\text { Kei Miyamoto et al. }\end{array}$ & Xenopus & $\begin{array}{l}\text { Nuclear Wave } 1 \\
\text { Oocyte nucleus }\end{array}$ & $\begin{array}{l}\text { One isoform of Wave enriched in brain } \\
\text { Activation of embryonic genes in Xenopus oocytes }\end{array}$ \\
\hline $\begin{array}{l}2014 \\
\text { Qingran Kong et al. }\end{array}$ & Porcine & $\begin{array}{l}\text { Vimentin } \\
\text { Oocyte factors }\end{array}$ & $\begin{array}{l}\text { Intermediate filament } \\
\text { Genomic protector and results in p } 53 \text { down-regulation }\end{array}$ \\
\hline $\begin{array}{l}2014 \\
\text { Wen et al. }\end{array}$ & Mouse & $\begin{array}{l}\text { H3.3 } \\
\text { Oocyte factors }\end{array}$ & $\begin{array}{l}\text { Histone variants } \\
\text { Replacement of donor nucleus-derived H3 with den ovo synthesized } \\
\text { maternal H3.3 protein }\end{array}$ \\
\hline $\begin{array}{l}2014 \\
\text { Gonzalez-Muñoz et al. }\end{array}$ & Human & $\begin{array}{l}\text { ASF1A and GDF9 } \\
\text { Enriched in metaphase II oocytes }\end{array}$ & $\begin{array}{l}\text { Histone remodeling chaperone } \\
\text { Acetylating H3K56, impacting the expression of core pluripotency genes }\end{array}$ \\
\hline
\end{tabular}

Note: none represents no related information in the research.

\section{Advantages and strategies of using proteins and small molecules in reprogramming}

Proteins and small molecules can be used to regulate biological processes including reprogramming and have distinct advantages over other approaches. Firstly, they can be synthesized in large quantities and stored for long periods until needed. Secondly, the effects are usually reversible and can often be tightly controlled by duration and concentration. Lastly, owing to their stability and easy manipulation, they are suitable for academic and industrial applications. Numerous proteins and small molecules, whether from feeder cells, serum or synthesized, have proved useful for establishing and maintaining ESCs, and many play vital roles in reprogramming, which allows genetic-free manipulation of stem cells(Li etal., 2014). Besides, reseachers identified small molecules can enhance genome editing in pluripotent stem cells through the CRISPR/Cas9 technology, thus the use of small molecules provides a simple and effective strategy to enhance precise genome engineering applications and facilitates the study of DNA repair mechanisms (Yu et al., 2015).

Hamatani et al., (Hamatani et al., 2008) also proposed that genome-wide gene expression data could be obtained from microscopic specimens such as oocytes and pre-implantation embryos due to technological advances. Understanding the highly fluctuating dynamics of proteins and small molecules in oocytes and early embryos will be invaluable for identifying novel factors and mechanisms governing reprogramming. However, discovering and characterizing these crucial molecular determinants of reprogramming remains a challenging task.

On the one hand, the low efficiency of somatic cells cloning using SCNT is a major barrier to the successful application of this technology, and our understanding of the mechanisms underlying nuclear reprogramming in SCNT must be expanded. The use of SCNT for generating stem cells from humans and other primates has been questioned for a variety of ethical and technical reasons. Furthermore, since the discovery of iPSCs, there has emerged a large body of opposition to the use of SCNT in humans, in- cluding therapeutic cloning. In contrast, the use of iPSCs holds tremendous potential for developing cell-based therapies for degenerative diseases, drug screening, and developing disease models via production of patient-specific stem cells (Peters et al., 2010). In September 2014, iPSCs were trialed for the first time, on a 70-year-old Japanese woman with a debilitating eye disease (http://www.nature.com/news/japanese-woman-is-first-recipientof-next-generation-stem-cells-1.15915). Researchers around the world have since been watching closely to see whether the cells can prevent further destruction of the retina while avoiding side effects such as inducing an immune reaction or inducing cancerous growth. Therefore, more and more such clinical trials are needed to confirm the safety of iPSCs for medical applications.

It is widely appreciated that the oocyte cytoplasmic milieu is the major factors controlling the conversion of differentiated somatic cells to pluripotent stem cells. For example, the oocyte factors BMPs, vimentin and GDF9 are known to play important roles in nuclear reprogramming and iPSCs generation. Notably, the same oocyte factors have opposite effects in different cell types or species. For instance, BMPs suppress differentiation in mouse ESCs (Ying et al., 2003) and promote somatic cell reprogramming in early mice embryos (Samavarchi-Tehrani et al., 2010), but arrest human somatic cell reprogramming (Chen et al., 2013b). Researchers must therefore pay particular attention when translating results between species.

\section{Conclusion}

Procedures for cellular reprogramming and for using iPSCs in clinical applications must be safe, rapid and effective, and should generate high quality pluripotent stem cells that are stable and reproducible. Reprogramming methods using SCNT and iPSCs have shown great potential. Since Dolly the sheep, SCNT has proven more popular for animal cloning experiments, although the use of methods employing iPSCs is growing. Rodriguez et al., (Rodriguez et al., 2012) investigated signalling pathways participating in the formation of the porcine inner cell mass, and this knowledge could be applied to the development of porcine iPSCs. Perfect 
reprogramming and production of high quality iPSCs remain the major targets, and expanding our knowledge of early embryonic development and ESCs differentiation will be important for achieving these aims. For instance, in 2015, Irie et al., (Irie et al., 2015) generated human primodial germ cells (PGCs) from ESCs and high quality naïve state iPSCs, and Sox17 is a critical specifier of human PGCs fate, it may contribute to a major ultimate goal for human health (Barrios et al., 2013).

High-throughput or next-generation sequencing is continuing to improve at pace, and is making increasingly important contributions to clinical and industrial applications. For example, de novo sequencing, whole genomes and transcriptomes resequencing, and single cell sequencing are now possible for detecting dymanic changes in reprogramming process. These powerful technologies have the potential to greatly expand our understanding of the mechanisms underlying reprogramming, and will assist our pursuit of perfect reprogramming methods.

In summary, both SCNT and iPSCs are highly influenced by specific proteins and small molecules that are present in oocytes and early embryos. This review has attempted to emphasize the pivotal roles that these proteins and small molecules play in governing somatic cell reprogramming.

\section{Acknowledgements}

This work is supported by National Natural Science Foundation of China (31272442).

\section{References}

AMIT, M., CARPENTER, M.K., INOKUMA, M.S., CHIU, C.P., HARRIS, C.P., WAKNITZ, M.A., ITSKOVITZ-ELDOR, J. and THOMSON, J.A. (2000). Clonally derived human embryonic stem cell lines maintain pluripotency and proliferative potential for prolonged periods of culture. Dev Biol 227: 271-278.

BAGUISI, A., BEHBOODI, E., MELICAN, D.T., POLLOCK, J.S., DESTREMPES, M.M., CAMMUSO, C., WILLIAMS, J.L., NIMS, S.D., PORTER, C.A., MIDURA, P. et al., (1999). Production of goats by somatic cell nuclear transfer. Nat Biotech 17: 456-461.

BARRIOS, F., IRIE, N. and SURANI, M.A. (2013). Perceiving signals, building networks, reprogramming germ cell fate. Int J Dev Biol 57: 123-132.

BETTHAUSER, J., FORSBERG, E., AUGENSTEIN, M., CHILDS, L., EILERTSEN, K., ENOS, J., FORSYTHE, T., GOLUEKE, P., JURGELLA, G., KOPPANG, R. et al., (2000). Production of cloned pigs from in vitro systems. Nat Biotechnol 18: 1055-1059.

BUGANIM, Y., MARKOULAKI, S., VAN WIETMARSCHEN, N., HOKE, H., WU, T., GANZ, K., AKHTAR-ZAIDI, B., HE, Y., ABRAHAM, B.J., PORUBSKY, D. et al., (2014). The developmental potential of iPSCs is greatly influenced by reprogramming factor selection. Cell Stem Cell 15: 295-309.

BUI, H.T., KWON, D.N., KANG, M.H., OH, M.H., PARK, M.R., PARK, W.J., PAIK, S.S., VAN THUAN, N. and KIM, J.H. (2012). Epigenetic reprogramming in somatic cells induced by extract from germinal vesicle stage pig oocytes. Development 139: 4330-4340.

BUI, H.T., WAKAYAMA, S., KISHIGAMI, S., KIM, J.H., VANTHUAN, N. and WAKAYAMA, T. (2008). The cytoplasm of mouse germinal vesicle stage oocytes can enhance somatic cell nuclear reprogramming. Development 135: 3935-3945.

BYRNE, J.A., SIMONSSON, S., WESTERN, P.S. and GURDON, J.B. (2003). Nuclei of adult mammalian somatic cells are directly reprogrammed to oct-4 stem cell gene expression by amphibian oocytes. Curr Biol 13: 1206-1213.

CAMPBELL, K.H., FISHER, P., CHEN, W.C., CHOI, I., KELLY, R.D., LEE, J.H. and $\mathrm{XHU}$, J. (2007). Somatic cell nuclear transfer: Past, present and future perspectives. Theriogenology 1: 3.

CHEN, J., GUO, L., ZHANG, L., WU, H., YANG, J., LIU, H., WANG, X., HU, X., GU, T., ZHOU, Z. et al., (2013a). Vitamin C modulates TET1 function during somatic cell reprogramming. Nat Genet 45: 1504-1509.
CHEN, J., LIU, H., LIU, J., QI, J., WEI, B., YANG, J., LIANG, H., CHEN, Y., WU, Y. GUO, L. et al., (2013b). H3K9 methylation is a barrier during somatic cell reprogramming into iPSCs. Nat Genet 45: 34-42.

CHEN, J., LIU, J., YANG, J., CHEN, Y., CHEN, J., NI, S., SONG, H., ZENG, L., DING, K. and PEI, D. (2011). BMPs functionally replace Klf4 and support efficient reprogramming of mouse fibroblasts by Oct4 alone. Cell Res 21: 205-212.

CHESNE, P., ADENOT, P.G., VIGLIETTA, C., BARATTE, M., BOULANGER, L. and RENARD, J.-P. (2002). Cloned rabbits produced by nuclear transfer from adult somatic cells. Nat Biotech 20: 366-369.

CHO, H.J., LEE, C.S., KWON, Y.W., PAEK, J.S., LEE, S.H., HUR, J., LEE, E.J., ROH, T.Y., CHU, I.S., LEEM, S.H. et al., (2010). Induction of pluripotent stem cells from adult somatic cells by protein-based reprogramming without genetic manipulation. Blood 116: 386-395.

CHUNG, Y.G., EUM, J.H., LEE, J.E., SHIM, S.H., SEPILIAN, V., HONG, S.W., LEE, Y., TREFF, N.R., CHOI, Y.H., KIMBREL, E.A. et al., (2014). Human somatic cell nuclear transfer using adult cells. Cell Stem Cell 14: 777-780.

CIBELLI, J.B. (2014). Human somatic cell nuclear transfer is alive and well. Cell Stem Cell 14: 699-701.

CIBELLI, J.B., STICE, S.L., GOLUEKE, P.J., KANE, J.J., JERRY, J., BLACKWELL, C., PONCE DE LEON, F.A. and ROBL, J.M. (1998). Cloned transgenic calves produced from nonquiescent fetal fibroblasts. Science 280: 1256-1258.

EGUCHI, A., LEE, G.O., WAN, F., ERWIN, G.S. and ANSARI, A.Z. (2014). Controlling gene networks and cell fate with precision-targeted DNA-binding proteins and small-molecule-based genome readers. Biochem J 462: 397-413.

ESTEBAN, M.A., WANG, T., QIN, B., YANG, J., QIN, D., CAI, J., LI, W., WENG, Z., CHEN, J., NI, S. et al., (2010). Vitamin C enhances the generation of mouse and human induced pluripotent stem cells. Cell Stem Cell 6: 71-79.

ESTEBAN, M.A., XU, J., YANG, J., PENG, M., QIN, D., LI, W., JIANG, Z., CHEN, J., DENG, K., ZHONG, M. et al., (2009). Generation of induced pluripotent stem cell lines from Tibetan miniature pig. J Biol Chem 284: 17634-17640.

EVANS, M.J. and KAUFMAN, M.H. (1981). Establishment in culture of pluripotential cells from mouse embryos. Nature 292: 154-156.

GALLI, C., LAGUTINA, I., CROTTI, G., COLLEONI, S., TURINI, P., PONDERATO, N., DUCHI, R. and LAZZARI, G. (2003). Pregnancy: A cloned horse born to its dam twin. Nature 424: 635-635.

GARDNER, R.L. and BROOK, F.A. (1997). Reflections on the biology of embryonic stem (ES) cells. Int J Dev Biol 41: 235-243.

GONZALEZ-MUNOZ, E., ARBOLEDA-ESTUDILLO, Y., OTU, H.H. and CIBELLI, J.B. (2014). Cell reprogramming. Histone chaperone ASF1Ais required for maintenance of pluripotency and cellular reprogramming. Science 345: 822-825.

GURDON, J.B. (1962). The developmental capacity of nuclei taken from intestinal epithelium cells of feeding tadpoles. J Embryol Exp Morphol 10: 622-640.

HAMATANI, T., YAMADA, M., AKUTSU, H., KUJI, N., MOCHIMARU, Y., TAKANO, M., TOYODA, M., MIYADO, K., UMEZAWA, A. and YOSHIMURA, Y. (2008). What can we learn from gene expression profiling of mouse oocytes? Reproduction 135: 581-92.

HAN, J., YUAN, P., YANG, H., ZHANG, J., SOH, B.S., LI, P., LIM, S.L., CAO, S. TAY, J., ORLOV, Y.L. et al., (2010). Tbx3 improves the germ-line competency of induced pluripotent stem cells. Nature 463: 1096-1100.

HANNA, J., CHENG, A.W., SAHA, K., KIM, J., LENGNER, C.J., SOLDNER, F. CASSADY, J.P., MUFFAT, J., CAREY, B.W. and JAENISCH, R. (2010). Human embryonic stem cells with biological and epigenetic characteristics similar to those of mouse ESCs. Proc Natl Acad Sci USA 107: 9222-9227.

HOCKEMEYER, D., SOLDNER, F., BEARD, C., GAO, Q., MITALIPOVA, M., DEKELVER, R.C., KATIBAH, G.E., AMORA, R., BOYDSTON, E.A., ZEITLER, B. et al., (2009). Efficient targeting of expressed and silent genes in human ESCs and iPSCs using zinc-finger nucleases. Nat Biotechnol 27: 851-857.

HOU, P., LI, Y., ZHANG, X., LIU, C., GUAN, J., LI, H., ZHAO, T., YE, J., YANG, W., LIU, K. et al., (2013). Pluripotent stem cells induced from mouse somatic cells by small-molecule compounds. Science 341: 651-654.

HUMPHREY, R.K., BEATTIE, G.M., LOPEZ, A.D., BUCAY, N., KING, C.C., FIRPO, M.T., ROSE-JOHN, S. and HAYEK, A. (2004). Maintenance of pluripotency in human embryonic stem cells is STAT3 independent. Stem Cells 22: 522-530.

ICHIDA, J.K., T, C.W.J., WILLIAMS, L.A., CARTER, A.C., SHI, Y., MOURA, M.T., ZILLER, M., SINGH, S., AMABILE, G., BOCK, C. et al., (2014). Notch inhibition allows oncogene-independent generation of iPS cells. Nat Chem Biol10:632-639. 
IRIE, N., WEINBERGER, L., TANG, W.W., KOBAYASHI, T., VIUKOV, S., MANOR, Y.S., DIETMANN, S., HANNA, J.H. and SURANI, M.A. (2015). SOX17 is a critical specifier of human primordial germ cell fate. Cell 160: 253-268.

KIM, D., KIM, C.H., MOON, J.I., CHUNG, Y.G., CHANG, M.Y., HAN, B.S., KO, S., YANG, E., CHA, K.Y., LANZA, R. et al., (2009). Generation of human induced pluripotent stem cells by direct delivery of reprogramming proteins. Cell Stem Cell 4: 472-476.

KIMURA, T., KAGA, Y., SEKITA, Y., FUJIKAWA, K., NAKATANI, T., ODAMOTO, M., FUNAKI, S., IKAWA, M., ABE, K. and NAKANO, T. (2015). Pluripotent stem cells derived from mouse primordial germ cells by small molecule compounds. Stem Cells 33: 45-55.

KOCABAS, A.M., CROSBY, J., ROSS, P.J., OTU, H.H., BEYHAN, Z., CAN, H., TAM, W.L., ROSA, G.J., HALGREN, R.G., LIM, B. et al., (2006). The transcriptome of human oocytes. Proc Natl Acad Sci USA 103: 14027-14032.

KONG, Q., XIE, B., LI, J., HUAN, Y., HUANG, T., WEI, R., LV, J., LIU, S. and LIU, Z. (2014). Identification and characterization of an oocyte factor required for porcine nuclear reprogramming. J Biol Chem 289: 6960-6968.

KRUEGER, W.H., SWANSON, L.C., TANASIJEVIC, B. and RASMUSSEN, T.P. (2010). Natural and artificial routes to pluripotency. Int J Dev Biol 54: 1545-1564.

KRUPALNIK, V. and HANNA, J.H. (2014). Stem cells: The quest for the perfect reprogrammed cell. Nature 511: 160-162.

KUMAR, R., DIMENNA, L., SCHRODE, N., LIU, T.C., FRANCK, P., MUNOZ-DESCALZO, S., HADJANTONAKIS, A.K., ZARRIN, A.A., CHAUDHURI, J., ELEMENTO, O. et al., (2013). AID stabilizes stem-cell phenotype by removing epigenetic memory of pluripotency genes. Nature 500: 89-92.

LEE, B.C., KIM, M.K., JANG, G., OH, H.J., YUDA, F., KIM, H.J., SHAMIM, M.H., KIM, J.J., KANG, S.K., SCHATTEN, G. et al., (2005). Dogs cloned from adult somatic cells. Nature 436: 641-641.

LEE, J., SAYED, N., HUNTER, A., AU, K.F., WONG, W.H., MOCARSKI, E.S., PERA, R.R., YAKUBOV, E. and COOKE, J.P. (2012). Activation of innate immunity is required for efficient nuclear reprogramming. Cell 151: 547-558.

LEE, J.H., LEE, J.B., SHAPOVALOVA, Z., FIEBIG-COMYN, A., MITCHELL, R.R., LARONDE, S., SZABO, E., BENOIT, Y.D. and BHATIA, M. (2014). Somatic transcriptome priming gates lineage-specific differentiation potential of human-induced pluripotent stem cell states. Nat Commun 5: 5605.

LI, X., ZHANG, P., WEI, C. and ZHANG, Y. (2014). Generation of pluripotent stem cells via protein transduction. Int. J. Dev. Biol 58: 21-27.

LI, Y., ZHANG, Q., YIN, X., YANG, W., DU, Y., HOU, P., GE, J., LIU, C., ZHANG, W., ZHANG, X. et al., (2011). Generation of iPSCs from mouse fibroblasts with a single gene, Oct4, and small molecules. Cell Res 21: 196-204.

LI, Z., SUN, X., CHEN, J., LIU, X., WISELY, S.M., ZHOU, Q., RENARD, J.-P., LENO, G.H. and ENGELHARDT, J.F. (2006). Cloned ferrets produced by somatic cell nuclear transfer. Dev Biol. 293: 439-448.

LIANG, P., LAN, F., LEE, A.S., GONG, T., SANCHEZ-FREIRE, V., WANG, Y., DIECKE, S., SALLAM, K., KNOWLES, J.W., WANG, P.J. et al., (2013). Drug screening using a library of human induced pluripotent stem cell-derived cardiomyocytes reveals disease-specific patterns of cardiotoxicity. Circulation 127: 1677-1691.

LIN, T., AMBASUDHAN, R., YUAN, X., LI, W., HILCOVE, S., ABUJAROUR, R., LIN, X., HAHM, H.S., HAO, E., HAYEK, A. et al., (2009). A chemical platform for improved induction of human iPSCs. Nat Methods 6: 805-808.

LIU, X., SUN, H., QI, J., WANG, L., HE, S., LIU, J., FENG, C., CHEN, C., LI, W., GUO, Y. et al., (2013). Sequential introduction of reprogramming factors reveals a time-sensitive requirement for individual factors and a sequential EMT-MET mechanism for optimal reprogramming. Nat Cell Biol 15: 829-838.

MAEKAWA, M., YAMAGUCHI, K., NAKAMURA, T., SHIBUKAWA, R., KODANAKA, I., ICHISAKA, T., KAWAMURA, Y., MOCHIZUKI, H., GOSHIMA, N. and YAMANAKA, S. (2011). Direct reprogramming of somatic cells is promoted by maternal transcription factor Glis1. Nature 474: 225-229.

MARTINS-TAYLOR, K. and XU, R.H. (2012). Concise review: Genomic stability of human induced pluripotent stem cells. Stem Cells 30: 22-27.

MARUOTTI, J., JOUNEAU, A. and RENARD, J.P. (2010). Faithful reprogramming to pluripotency in mammals - what does nuclear transfer teach us? Int J Dev Biol 54: 1609-1621.

MIYAMOTO, K., NAGAI, K., KITAMURA, N., NISHIKAWA, T., IKEGAMI, H., BINH, N.T., TSUKAMOTO, S., MATSUMOTO, M., TSUKIYAMA, T., MINAMI, N. et al., (2011). Identification and characterization of an oocyte factor required for development of porcine nuclear transfer embryos. Proc Natl Acad Sci USA 108: 7040-705.

MIYAMOTO, K., TEPEREK, M., YUSA, K., ALLEN, G.E., BRADSHAW, C.R. and GURDON, J.B. (2013). Nuclear Wave1 is required for reprogramming transcription in oocytes and for normal development. Science 341: 1002-1005.

MIYOSHI, N., ISHII, H., NAGANO, H., HARAGUCHI, N., DEWI, D.L., KANO, Y., NISHIKAWA, S., TANEMURA, M., MIMORI, K., TANAKA, F. et al., (2011). Reprogramming of mouse and human cells to pluripotency using mature microRNAs. Cell Stem Cell 8: 633-638.

NICHOLS, J. and SMITH, A. (2009). Naive and primed pluripotent states. Cell Stem Cell 4: 487-492.

OKITA, K., ICHISAKA, T. and YAMANAKA, S. (2007). Generation of germline-competent induced pluripotent stem cells. Nature 448: 313-317.

OKITA, K., MATSUMURA, Y., SATO, Y., OKADA, A., MORIZANE, A., OKAMOTO, S., HONG, H., NAKAGAWA, M., TANABE, K., TEZUKA, K. etal., (2011). Amore efficient method to generate integration-free human iPS cells. Nat Methods 8: 409-412.

OKITA, K., NAKAGAWA, M., HYENJONG, H., ICHISAKA, T. and YAMANAKA, S. (2008). Generation of mouse induced pluripotent stem cells without viral vectors. Science 322: 949-953.

PARADIS, F., NOVAK, S., MURDOCH, G.K., DYCK, M.K., DIXON, W.T. and FOXCROFT, G.R. (2009). Temporal regulation of BMP2, BMP6, BMP15, GDF9, BMPR1A, BMPR1B, BMPR2 and TGFBR1 mRNA expression in the oocyte, granulosa and theca cells of developing preovulatory follicles in the pig. Reproduction 138: 115-129.

PARK, I.-H., ARORA, N., HUO, H., MAHERALI, N., AHFELDT, T., SHIMAMURA, A., LENSCH, M.W., COWAN, C., HOCHEDLINGER, K. and DALEY, G.Q. (2008). Disease-Specific Induced Pluripotent Stem Cells. Cell 134: 877-886.

PETERS, A., BURRIDGE, P.W., PRYZHKOVA, M.V., LEVINE, M.A., PARK, T.S. ROXBURY, C., YUAN, X., PEAULT, B. and ZAMBIDIS, E.T. (2010). Challenges and strategies for generating therapeutic patient-specific hemangioblasts and hematopoietic stem cells from human pluripotent stem cells. Int J Dev Biol 54: 965-990.

POLEJAEVA, I.A., CHEN, S.-H., VAUGHT, T.D., PAGE, R.L., MULLINS, J., BALL, S., DAI, Y., BOONE, J., WALKER, S., AYARES, D.L. et al., (2000). Cloned pigs produced by nuclear transfer from adult somatic cells. Nature 407: 86-90.

POLO, J.M., LIU, S., FIGUEROA, M.E., KULALERT, W., EMINLI, S., TAN, K.Y., APOSTOLOU, E., STADTFELD, M., LI, Y., SHIODA, T. et al., (2010). Cell type of origin influences the molecular and functional properties of mouse induced pluripotent stem cells. Nat Biotech 28: 848-855.

RODRIGUEZ, A., ALLEGRUCCI, C. and ALBERIO, R. (2012). Modulation of pluripotency in the porcine embryo and iPS cells. PLoS One 7: 8.

SAMAVARCHI-TEHRANI, P., GOLIPOUR, A., DAVID, L., SUNG, H.K., BEYER, T.A., DATTI, A., WOLTJEN, K., NAGY, A. and WRANA, J.L. (2010). Functional genomics reveals a BMP-driven mesenchymal-to-epithelial transition in the initiation of somatic cell reprogramming. Cell Stem Cell 7: 64-77.

SHI, D., LU, F., WEI, Y., CUI, K., YANG, S., WEI, J. and LIU, Q. (2007). Buffalos (Bubalus bubalis) cloned by nuclear transfer of somatic cells. Biol Reprod 77: 285-91.

SHIN, T., KRAEMER, D., PRYOR, J., LIU, L., RUGILA, J., HOWE, L., BUCK, S., MURPHY, K., LYONS, L. and WESTHUSIN, M. (2002). A cat cloned by nuclear transplantation. Nature 415: 859

SHINAGAWA, T., TAKAGI, T., TSUKAMOTO, D., TOMARU, C., HUYNH, L.M., SIVARAMAN, P., KUMAREVEL, T., INOUE, K., NAKATO, R., KATOU, Y. et al., (2013). Histone variants enriched in oocytes enhance reprogramming to induced pluripotent stem cells. Cell Stem Cell 14: 217-227.

SHU, J., ZHANG, K., ZHANG, M., YAO, A., SHAO, S., DU, F., YANG, C., CHEN, W., WU, C., YANG, W. et al., (2015). GATA family members as inducers for cellular reprogramming to pluripotency. Cell Res 25: 169-180.

SILVA, J., BARRANDON, O., NICHOLS, J., KAWAGUCHI, J., THEUNISSEN, T.W. and SMITH, A. (2008). Promotion of reprogramming to ground state pluripotency by signal inhibition. PLOS Biol 6: e253.

SONG, Y., HAI, T., WANG, Y., GUO, R., LI, W., WANG, L. and ZHOU, Q. (2013). Epigenetic reprogramming, gene expression and in vitro development of porcine SCNT embryos are significantly improved by a histone deacetylase inhibitor--mcarboxycinnamic acid bishydroxamide (CBHA). Protein Cell 5: 382-393.

STADTFELD, M., NAGAYA, M., UTIKAL, J., WEIR, G. and HOCHEDLINGER, K (2008). Induced pluripotent stem cells generated without viral integration. Science 322: 945-949.

TACHIBANA, M., AMATO, P., SPARMAN, M., GUTIERREZ, N.M., TIPPNER-HEDGES, 
R., MA, H., KANG, E., FULATI, A., LEE, H.S., SRITANAUDOMCHAI, H. et al., (2013). Human embryonic stem cells derived by somatic cell nuclear transfer. Cell 153: 1228-1238.

TAKAHASHI, K., TANABE, K., OHNUKI, M., NARITA, M., ICHISAKA, T., TOMODA, K. and YAMANAKA, S. (2007). Induction of pluripotent stem cells from adult human fibroblasts by defined factors. Cell 131: 861-872.

TAKAHASHI, K. and YAMANAKA, S. (2006). Induction of pluripotent stem cells from mouse embryonic and adult fibroblast cultures by defined factors. Cell126:663-676.

THOMSON, J.A., ITSKOVITZ-ELDOR, J., SHAPIRO, S.S., WAKNITZ, M.A., SWIERGIEL, J.J., MARSHALL, V.S. and JONES, J.M. (1998). Embryonic stem cell lines derived from human blastocysts. Science 282: 1145-1147.

TSUBOOKA, N., ICHISAKA, T., OKITA, K., TAKAHASHI, K., NAKAGAWA, M. and YAMANAKA, S. (2009). Roles of Sall4 in the generation of pluripotent stem cells from blastocysts and fibroblasts. Genes Cells 14: 683-694.

WAKAYAMA, T., PERRY, A.C.F., ZUCCOTTI, M., JOHNSON, K.R. and YANAGIMACHI, R. (1998). Full-term development of mice from enucleated oocytes injected with cumulus cell nuclei. Nature 394: 369-374.

WANG, J., GU, Q., HAO, J., JIA, Y., XUE, B., JIN, H., MA, J., WEI, R., HAI, T., KONG, Q. et al., (2013). Tbx3 and Nr5alpha2 play important roles in pig pluripotent stem cells. Stem Cell Rev 9: 700-708.

WANG, T., CHEN, K., ZENG, X., YANG, J., WU, Y., SHI, X., QIN, B., ZENG, L., ESTEBAN, M.A., PAN, G. et al., (2011). The histone demethylases Jhdm1a/1b enhance somatic cell reprogramming in a vitamin-C-dependent manner. Cell Stem Cell 9: 575-587.

WARE, C.B., NELSON, A.M., MECHAM, B., HESSON, J., ZHOU, W., JONLIN, E.C., JIMENEZ-CALIANI, A.J., DENG, X., CAVANAUGH, C., COOK, S. et al., (2014). Derivation of naive human embryonic stem cells. Proc Natl Acad Sci USA 111: 4484-4489.

WARREN, L., MANOS, P.D., AHFELDT, T., LOH, Y.H., LI, H., LAU, F., EBINA, W., MANDAL, P.K., SMITH, Z.D., MEISSNER, A. et al., (2010). Highly efficient reprogramming to pluripotency and directed differentiation of human cells with synthetic modified mRNA. Cell Stem Cell 7: 618-630.

WEN, D., BANASZYNSKI, L.A., LIU, Y., GENG, F., NOH, K.M., XIANG, J., ELEMENTO, O., ROSENWAKS, Z., ALLIS, C.D. and RAFII, S. (2014). Histone variant H3.3 is an essential maternal factor for oocyte reprogramming. Proc Natl Acad Sci USA 111: 7325-30

WILMUT, I., SCHNIEKE, A.E., MCWHIR, J., KIND, A.J. and CAMPBELL, K.H. (1997) Viable offspring derived from fetal and adult mammalian cells. Nature 385:810-813.

XU, R.H., CHEN, X., LI, D.S., LI, R., ADDICKS, G.C., GLENNON, C., ZWAKA, T.P. and THOMSON, J.A. (2002). BMP4 initiates human embryonic stem cell differentiation to trophoblast. Nat Biotechnol. 20: 1261-1264.

YAMADA, M., JOHANNESSON, B., SAGI, I., BURNETT, L.C., KORT, D.H., PROSSER, R.W., PAULL, D., NESTOR, M.W., FREEBY, M., GREENBERG, E. et al., (2014). Human oocytes reprogram adult somatic nuclei of a type 1 diabetic to diploid pluripotent stem cells. Nature 510: 533-536.

YING, Q.L., NICHOLS, J., CHAMBERS, I. and SMITH, A. (2003). BMP induction of Id proteins suppresses differentiation and sustains embryonic stem cell self-renewal in collaboration with STAT3. Cell 115: 281-292.

YU, C., LIU, Y., MA, T., LIU, K., XU, S., ZHANG, Y., LIU, H., LA RUSSA, M., XIE, M., DING, S. et al., (2015). Small molecules enhance CRISPR genome editing in pluripotent stem cells. Cell Stem Cell 16: 142-147.

YU, J., HU, K., SMUGA-OTTO, K., TIAN, S., STEWART, R., SLUKVIN, II and THOMSON, J.A. (2009). Human induced pluripotent stem cells free of vector and transgene sequences. Science 324: 797-801.

YU, J., VODYANIK, M.A., SMUGA-OTTO, K., ANTOSIEWICZ-BOURGET, J., FRANE, J.L., TIAN, S., NIE, J., JONSDOTTIR, G.A., RUOTTI, V., STEWART, R. et al., (2007). Induced pluripotent stem cell lines derived from human somatic cells. Science 318: 1917-1920.

ZHANG, Y., WEI, C., ZHANG, P., LI, X., LIU, T., PU, Y., LI, Y., CAO, Z., CAO, H. LIU, Y. et al., (2014). Efficient reprogramming of naive-like induced pluripotent stem cells from porcine adipose-derived stem cells with a feeder-independent and serum-free system. PLoS One 9: e85089.

ZHAO, T., ZHANG, Z.N., RONG, Z. and XU, Y. (2011). Immunogenicity of induced pluripotent stem cells. Nature 474: 212-215.

ZHOU, Q., RENARD, J.P., LE FRIEC, G., BROCHARD, V., BEAUJEAN, N., CHERIFI, Y., FRAICHARD, A. and COZZI, J. (2003). Generation of fertile cloned rats by regulating oocyte activation. Science 302: 1179. 


\section{Further Related Reading, published previously in the Int. J. Dev. Biol.}

\section{Generation of pluripotent stem cells via protein transduction}

Xia Li, Pengfei Zhang, Chao Wei and Yunhai Zhang

Int. J. Dev. Biol. (2014) 58: 21-27

http://dx.doi.org/10.1387/ijdb.140007XL

Porcine induced pluripotent stem cells analogous to naïve and primed embryonic stem cells of the mouse Bhanu Prakash V.L. Telugu, Toshihiko Ezashi and R. Michael Roberts

Int. J. Dev. Biol. (2010) 54: 1703-1711

http://dx.doi.org/10.1387/ijdb.103200bt

Faithful reprogramming to pluripotency in mammals - what does nuclear transfer teach us?

Julien Maruotti, Alice Jouneau and Jean-Paul Renard

Int. J. Dev. Biol. (2010) 54: 1609-1621

http://dx.doi.org/10.1387/ijdb.103195jm

Reprogramming cell fate to pluripotency: the decision-making signalling pathways Daniela Sanges and Maria-Pia Cosma

Int. J. Dev. Biol. (2010) 54: 1575-1587

http://dx.doi.org/10.1387/ijdb.103190ds

The influence of donor nucleus source on the outcome of zebrafish somatic cell nuclear transfer

Kannika Siripattarapravat, Boonya Pinmee, Eun-Ah Chang, Juan D. Muñoz, Koichi Kawakami and José B. Cibelli

Int. J. Dev. Biol. (2010) 54: 1679-1683

http://dx.doi.org/10.1387/ijdb.103189ks

5 yr ISI Impact Factor $(2013)=2.879$
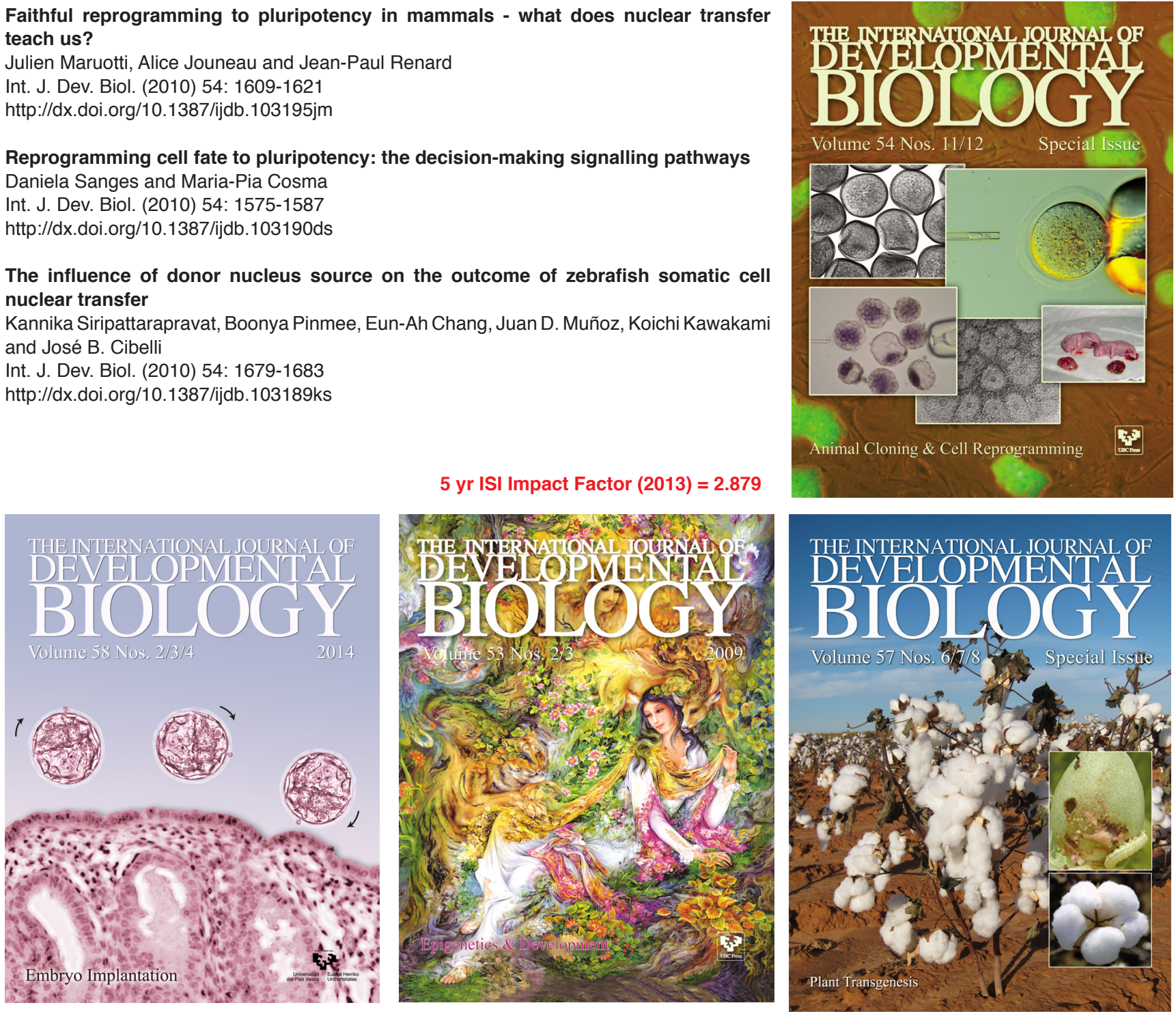